\title{
Analysis of the Influence of Website Quality to Customer's Loyalty on E-Commerce
}

\author{
Candiwan \\ Telkom University \\ candiwan@telkomuniversity.ac.id \\ CokroWibisono \\ Telkom University \\ cokro.wibi@gmail.com
}

\begin{abstract}
The competition of e-commerce in Indonesia makes domestic and foreign ecommerce companies plan strategies to win the competition. Customer's loyalty is an important factor to lead in the competition. This research focuses on how much influence of the website quality on customer's loyalty. This study also finds out which factor of website quality has the most influence on customer's loyalty with customer's satisfaction as a mediating factor. Factors that influence e-commerce customer's loyalty were analysed using the WebQual4.0 method which consists of three dimensions. The samples used in this research were 400 respondents. The data analysis techniques used were Structural Equational Model (SEM) using version 3.0 SmartPLS and Importance and Performance Map Analysis (IPMA). The analysis of SEM showed that the information quality was the only one that had a positive and significant influence on customer's satisfaction and loyalty on the JD.id website, while the usability and service factors had no positive and significant effect. The analysis of IPMA showed that the performances that should be improved were the maintenance of accurate and detailed information and content development.
\end{abstract}

Keywords: SmartPLS, SEM, WebQual 4.0, Usability, Information Quality, Service Interaction Quality, JD.id

\section{INTRODUCTION}

\subsection{Research Background}

Because of the growth of internet users, a large number of websites have appeared to provide various daily needs, one of which is online shopping (ecommerce) website. The number of online businesses that have emerged in Indonesia is also caused by the number of internet users continuing to grow every year. It ranks in the fifth position globally, reaching 143.26 million users with growth up to $21 \%$ [1]. The internet is used in various gadgets, such as smartphones, laptops, personal computers, and other devices thereby encouraging consumptive behaviour via the internet. The value of e-commerce retail sales in Indonesia increases by up to $21 \%$ each year and is predicted to keep increasing. This is an opportunity for e-commerce businesses to open branches in Indonesia, including the JD.id website [2]. 
The JD.id website grows rapidly with various efforts to improve the quality of the website and the services provided. One of the features not provided by some other e-commerce businesses is a news source, which provides all information about JD.id, ranging from product promos, lifestyle, news updates, corporate news, and seller updates. It can be accessed through JD news on the JD.id main menu with the aim to provide complete and up-to-date information to users about what is happening on the JD.id website. Besides JD news, JD.id also wants to attract the trust of the community and users by presenting a fast delivery process. Because of this, JD.id decided to build warehouses in Jakarta, Surabaya, Pontianak, and Medan. In February 2018, JD.id built a new warehouse in Makassar. JD.id's services are also widespread, in which JD.id initially only provided physical goods. Today, JD.id provides a variety of nonphysical services, such as cellular pulse charging, data package purchases, cinema ticket booking, and flight ticket booking via JD Flight [3].

JD Indonesia has prepared several strategies to compete in the Indonesia ecommerce market, one of which is building customer's experience. Other than building customer's experience, JD.id has come up with the idea of increasing the quality of the website by adding some new aspects that its competitors don't have. It indicates that JD.id realises that website quality is one of the key factors for customer's satisfaction [4]. The website quality is measured based on WebQual 4.0 that is usually used by the website of online shopping [5]. Customer's satisfaction affects customer's loyalty because one's experience with companies can shape behaviour. When getting good service from the company, the customer will repeat their experience with the company and then, finally, customer's loyalty is established [6]. Therefore, there is a special need to understand website quality and examine which factors influence users' positive experience so that users are willing to return to the website, recommend it to others, and also tend to remain accessing the JD.id website rather than other websites.

This research is conducted based on previous researches analysing website quality towards customer's satisfaction and customer's loyalty with different use of model and industry. Le Van Huy and Tuyen[7]studied about how website quality affects customer's satisfaction and customer's loyalty on banking websites using a regression model. Also, Kartikasari researched[8] about how website quality influences customer's satisfaction and customer's loyalty on library websites using the SEM-PLS model.

This research was also conducted to identify the influence of website quality on customer's loyalty with customer's satisfaction as a mediating factor in the online retail sector in which such research has not been previously conducted. Thus, this research might help existing and start-up online retailers to be aware of the importance of website quality in online business to win the competition. This may enhance the performance of the website by understanding which part of the JD.id website needs to improve.

\subsection{Problem Formulation}

Based on the research background described above, there are four research questions that can be formulated:

1.What are the website quality factors that influence customer's satisfaction on the JD.id website? 
2.What is the effect of customer's satisfaction as a mediator to customer's loyalty on the JD.id website?

3. What are the website quality factors that influence customer's loyalty with customer's satisfaction as a mediator on the JD.id website?

4. What are the factors of website quality and customer's satisfaction that need to be considered in increasing customer's loyalty?

\section{2.. LITERATURE STUDY}

\subsection{WebQual 4.0}

WebQual (www.webqual.co.uk) is a measurement based on Quality Function Deployment (QFD). QFD is a product development system that starts from designing products, manufacturing processes, until the products are in the hands of consumers, wherein product development is based on consumer's satisfaction. Website Quality is one of the concepts used in measuring website quality based on the perception of endusers. This concept is the development of SERVQUAL, which is widely used previously in measuring service quality. Website Quality, or commonly called WebQual, has been developed since 1998 and has undergone several iterations in the preparation of dimensions and items of questions [9].

WebQual is a method for researching a website based on the perception of the end-user of the website. In WebQual, there are several criteria for assessing a website. This WebQual method has four versions, ranging from version 1.0 to version 4.0[10]. In the Internet environment, users are both providers and consumers of information and services. The ease on web pages that have been published has created numerous problems, such as incorrect or out-of-date information, inappropriate navigation, and broken links. Whereas, usability, information, and service quality influence the effectiveness of the website. These factors are issues that will determine the ability of businesses to reap the benefits of e-commerce [10]. Usability focuses on how the website performs and how the website can help users to access the website well. Information quality focuses on how good the information is provided. Service interaction quality shows how the website interacts with the users and how well the website solves the problems of the users [10]. Dimension and variable of website quality are constructed based on the opinion of the web users based on Barnes and Vidgen's research[10]. WebQual version 4.0 is the latest version of the three previous versions. It has three main categories: usability, information quality, and service interaction with 23 points in total. In the WebQual version 4.0 category, website, information quality, and service interaction dimensions contained in the previous versions are replaced by usability, information quality, and service interaction dimensions [11]. 
Table 1. Dimension and variables of WebQual 4.0

\begin{tabular}{|c|c|}
\hline Dimension & WebQual Variables \\
\hline Usability & $\begin{array}{l}\text { 1. I find the site is easy to learn and to operate (X1a) } \\
\text { 2. My interaction with the site is clear and } \\
\text { understandable (X1b) } \\
\text { 3. I find the site is easy to navigate (X1c) } \\
\text { 4. I find the site is easy to use (X1d) } \\
\text { 5. The site has an attractive appearance (X1e) } \\
\text { 6. The design is appropriate to the type of site (X1f) } \\
\text { 7. The site conveys a sense of competency (X1g) } \\
\text { 8. The site creates a positive experience for me (X1h) }\end{array}$ \\
\hline $\begin{array}{l}\text { Information } \\
\text { quality }\end{array}$ & $\begin{array}{l}\text { 1. The site has accurate information }(\mathrm{X} 2 \mathrm{a}) \\
\text { 2. The site provides reliable information }(\mathrm{X} 2 \mathrm{~b}) \\
\text { 3. The site has up-to-date information }(\mathrm{X} 2 \mathrm{c}) \\
\text { 4. The site provides precise information }(\mathrm{X} 2 \mathrm{~d}) \\
\text { 5. The site provides relevant information }(\mathrm{X} 2 \mathrm{e}) \\
\text { 6. The site provides ease to understand information } \\
(\mathrm{X} 2 \mathrm{f}) \\
\text { 7. The site provides information at the right level of } \\
\text { detail }(\mathrm{X} 2 \mathrm{~g})\end{array}$ \\
\hline $\begin{array}{l}\text { Service } \\
\text { Interaction } \\
\text { quality }\end{array}$ & $\begin{array}{l}\text { 1. The site has a good reputation (X3a) } \\
\text { 2. The site feels safe to complete transactions }(\mathrm{X} 3 \mathrm{~b}) \\
\text { 3. The site creates a sense of personalisation }(\mathrm{X} 3 \mathrm{c}) \\
\text { 4. The site conveys a sense of customer's loyalty }(\mathrm{X} 3 \mathrm{~d}) \\
\text { 5. The site makes it easy to communicate with the } \\
\text { organisation (X3e) } \\
\text { 6. I feel confident that goods/services will be delivered } \\
\text { as promised (X3f) }\end{array}$ \\
\hline $\begin{array}{l}\text { Overall } \\
\text { impression }\end{array}$ & Overall website \\
\hline
\end{tabular}

\subsection{Customer's satisfaction}

Customer's satisfaction is a feeling of being satisfied or disappointed after comparing the expectations with the reality obtained. High satisfaction or pleasure creates an emotional bond towards a certain brand or company. Based on these opinions, it can be said that customer's satisfaction is closely related to two things, expectations and results received. Customer's satisfaction is the agreement between expectations and perceptions of services received (results obtained or reality experienced). Customer's satisfaction is created during the purchase period, experience using the product or service, and the period after the purchase. Customers who are satisfied with the products they use will return to use the products offered. The result of customer's satisfaction is one of the most important factors to win the competition [12]. Increased customer's satisfaction can provide company benefits like customer's loyalty, extend the life cycle of a customer, expand the life of merchandise that the customer purchase, and increase customers' positive word of mouth communication. When the customer is satisfied with the product or service of the company, the customer will purchase products or services frequently and recommend them to potential customers. It is impossible for a business organization to grow up if 
the company ignores or disregards the needs of customers[13].The explorative review and meta-analysis of research findings have generated a model that conceptualizes product pricing, trust, product quality, and services as the driving forces for customer's satisfaction. The model name is the Customer's Satisfaction Model. The purpose of the model is to offer a simplistic overview of the assessment of the customer's satisfaction. The research focused on trust, product quality, product pricing, and customer service. These are the principal elements that are necessary to assess the analysis of the customer's satisfaction[14]. The indicators of satisfied customers are having a good experience (Y1a), meeting their expectations (Y1b), believing that the product or service provided is satisfactory (Y1c), and providing the entire products or services that make customers happy (Y1d).

\subsection{Customer's loyalty}

Loyalty is the behaviour of consumers who carry out buying behaviour, which is defined as non-random purchases that are disclosed from time to time by several decision-making units. Loyal customers have specific prejudices about what they want to buy repeatedly [15].

The characteristics of loyal customers are making regular repurchases (Y2a), buying product lines and services (Y2b), giving referrals to other people (Y2c), and demonstrating immunity from competitors' attractiveness (Y2d).

\section{RESEARCH METHOD}

\subsection{Research Model}

The research method used in this study was quantitative research. The purpose of this research was conclusive by looking at and reading previous studies that discussed the relationship among variables, then examining whether the relationships among variables that occurred in previous studies also occurred in the object being examined [16].

The population of this research was all JD.id website visitors. For the sake of a more efficient research process, a sample of the existing population was JD.id website users. It was based on the Yamane formula which produced a sample of 400 people spread through Google doc online for users who had used the JD.id website before [10].

The framework model used in this research was referenced from Kartikasari[8] and Le Van Huy and Tuyen's[7] research in which there is a need to be a mediating factor to examine the quality of the website towards customer's loyalty. The framework of this research was also supported by research from Manasra, "Zaid and Taher Qutaishat[17], Abbaspour and Hashim[18] and Napitupulu[19] in which customer's satisfaction was more appropriate to be a mediating factor than other factors.

Based on previous researches, some factors of website quality were important towards satisfaction and loyalty level. Using the SEM model, Kartikasari[8] showed that usability had a significant and positive effect on user's satisfaction and user's loyalty on the university library's websites. The usability variable was also supported by Napitupulu[19] who showed that usability had a positive and significant effect on 
user's satisfaction through a regression model. They concluded that the usability variable might affect satisfaction and loyalty levels on retail websites as well.

Other than usability, information quality also affects satisfaction and loyalty level. Research by Le Van Huy and Tuyen[7] showed that information quality had a positive effect on loyalty and satisfaction levels in the banking industry. Research by Abbaspour and Hashim[18] also showed the same result on travel websites. It is concluded that the information quality variable might affect satisfaction and loyalty levels on retail websites as well.

According to Manasra, Zaid, and Taher Qutaishat[17], besides, information quality, service interaction also affects satisfaction and loyalty level. Their research showed that service interaction had a positive effect on satisfaction and loyalty levels in the telecommunication sector. It is concluded that the service interaction variable might affect satisfaction and loyalty levels on retail websites as well. Furthermore, satisfaction has a significant role to build customer's loyalty and can also encourage the continued activity of online transactions[20]. Satisfaction is a mediator for the relationship between quality and loyalty and will cause the potential of long term loyalty [21]. A satisfied customer buys the same product or service repeatedly from a service provider and refuses the competitive offers [22].

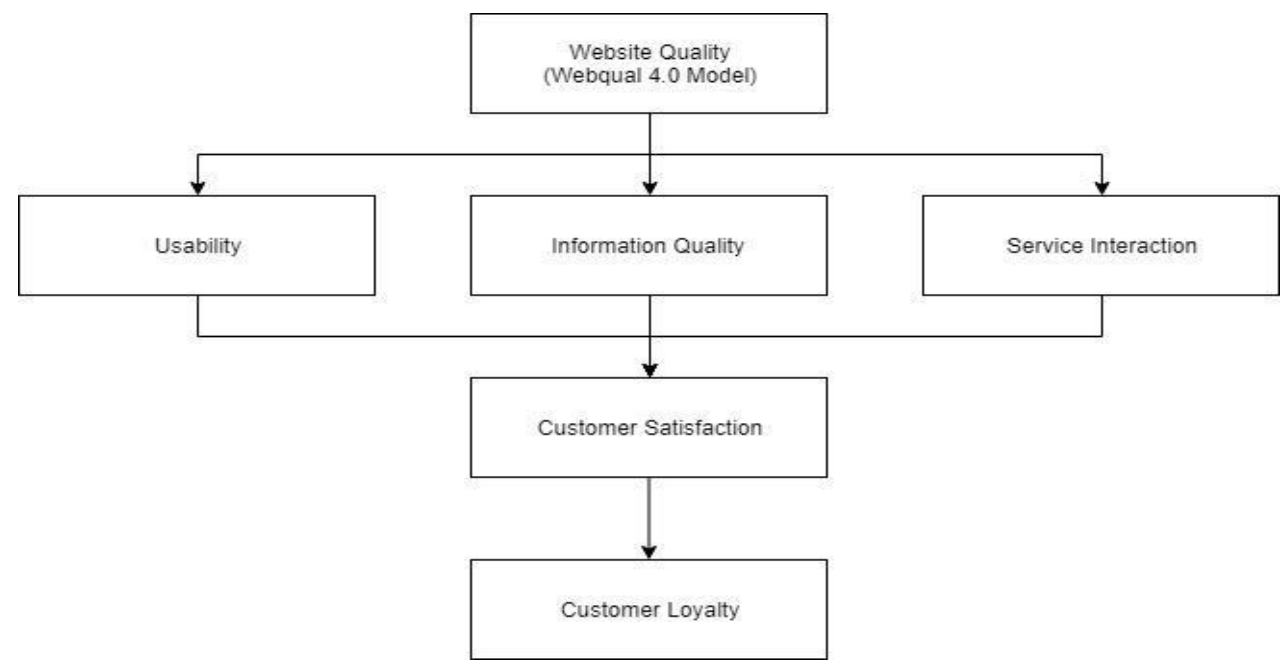

Figure 1. Research model

\subsection{Research Method}

This research used Importance and Performance Map Analysis (IPMA) and Structural Equation Modelling (SEM) SEM-PLS because the researcher wants to know the relationship among three independent variables of website quality, namely, usability, information quality and service interaction in regard to the customer's loyalty with customer's satisfaction as mediation. PLS has two evaluation models: outer model (measurement model) and inner model (structural model) [23].

The outer model evaluates or tests indicators, which consist of the validity of loading factor, cross-loading, and Average Variance Extracted (AVE). Reliability is Construct Reliability (CR), Cronbach's alpha [23]. Discriminant validity uses HTMT method [24]. 
The inner model evaluates or tests the influence among latent variables. Inner model testing consists of r-square, which is a value of the construct when studying to what degree latent variables can explain the variance of a variable which is known as the coefficient of determination. Q-square is a predictive relevance or criterion of impact relative to the inner model obtained from blindfolding inner models or structural models. F-square is the effect size of one latent variable directly to another latent variable. Hypothesis testing is in the form of a statistical t-test obtained through bootstrap from the structural model [25].

This research does not use Covariant Based SEM (CB-SEM) but uses Partial Least Square (PLS-SEM) because this research uses predictive orientation with more developing theories. It is used because most of the quality of websites using the WebQual method is only to determine the influence among dimensions of website quality to customer's satisfaction, not to customer's loyalty. In addition to being predictive, all variables from this research do not have a correlation or are interconnected in two directions, but lead to just one variable. PLS-SEM is more appropriate to use if the variable does not have a correlation between one variable and the others. PLS-SEM is used in this research because this research aims to examine the predictive relationship with the construct as to whether there is a relationship or influence among the constructs studied [26].

This research uses IPMA which is a two-dimensional map that is used to classify a construct or indicator based on the results of a survey that has been conducted to find suggestions for development based on scores from the Importance and Performance of variables and indicators. The results of IPMA can provide information about important constructs and provide information about each indicator, one of which should be focused and the others do not need to be considered [27]. IPMA is conducted in this research to gain additional results and findings by expanding the analysis to the indicator level identifying the most important area of specific actions [27].

The research step conducted, the first step is to determine the individual construct. This step relates to the development of hypotheses (based on theory) as the basis for connecting latent variables with their indicators. The model which forms a perception of how latent variables are measured by observed variables is based on theory and evidence obtained. The conceptualization of this model must also reflect the measurement of latent variables through various indicators that can be measured. The second stage is developing and determining the model measurement. The third stage is conducting studies to produce empirical data. At this stage, the main concern is determining the type of data to be analyzed, either correlation matrix or covariance matrix, sample size, proposed structural models, estimation techniques used, software computer to be used. The fourth step is testing the validity of the measurement model. At this stage, preliminary testing of the validity of the model we use is carried out. Many parameters can be used as a reference to determine whether a model is acceptable. After the measurement model shows acceptable results, a structural model is made in the SEM program that will be used and prepared for estimation. The sixth stage in the SEM is the Assessment of Structural Model Validity. A model is said to be fit if the covariance matrix of a model (model-based Covariance Matrix) is the same as the data matrix covariance (observed)[23].

The model of the structural equation model from the research can be seen in Figure 2 below: 


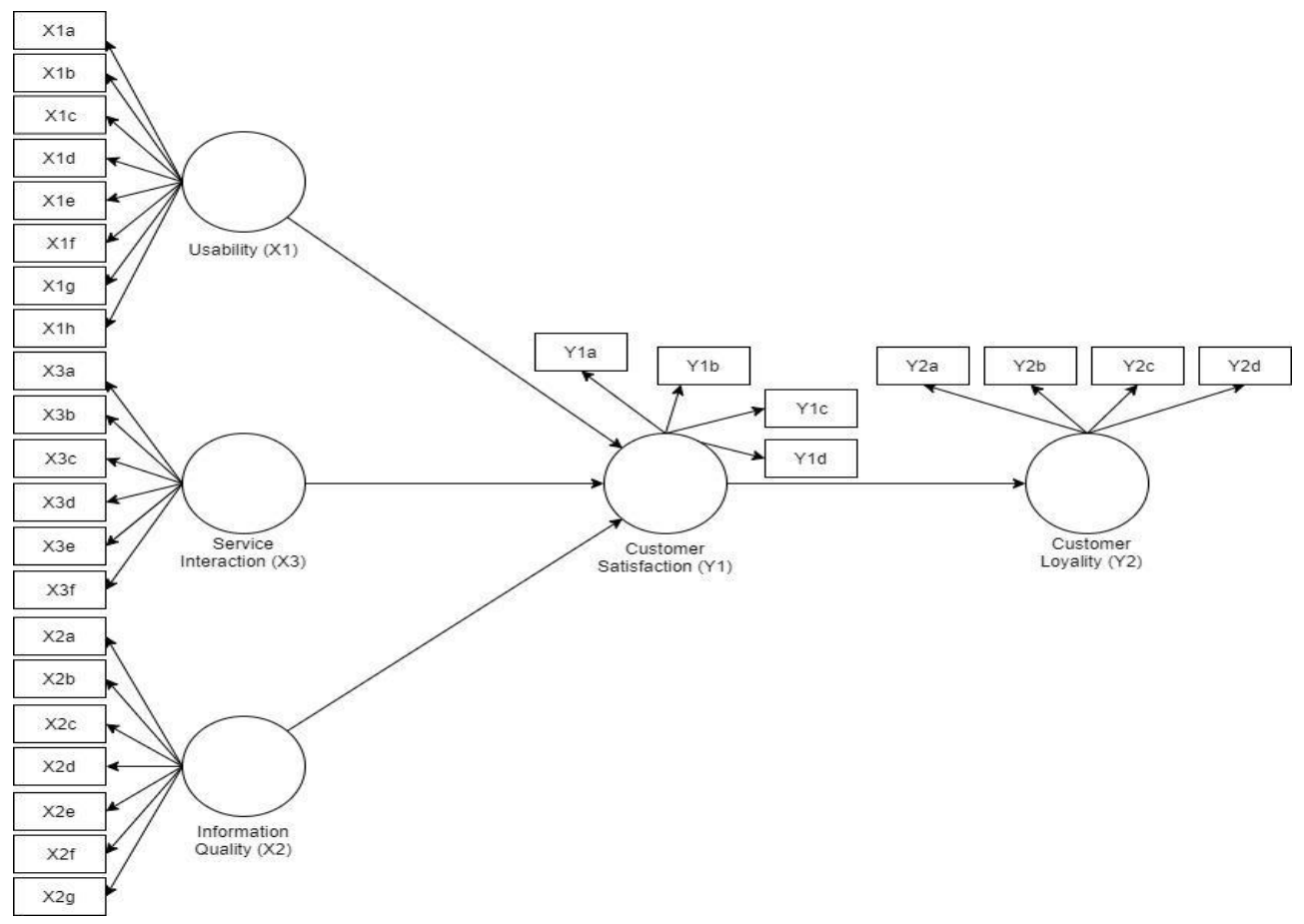

Figure 2. Structural equation model

\section{RESULT AND DISCUSSION}

\subsection{Respondent Characteristics}

Based on data from 400 respondents, JD.id website users were dominated by female users by $58 \%$ or 230 users, while male users were $42 \%$ or as many as 170 users.

Users of JD.id website are dominated by users aged 17 to 24 years old at $66 \%$ or 264 users, aged 24 to 30 years old at $17 \%$ or 68 users, aged 30 to 40 years old $8.5 \%$ or 34 users and aged 40 old and above by $8.5 \%$, or as many as 34 users.

Users of the JD.id website are evenly distributed in education level to high school, bachelor, and diploma. Users of the JD.id website of high school or equivalent are $44 \%$ or as many as 176 users, then users of bachelor education are $41 \%$ or 164 users, and users of diploma education are $15 \%$ or 60 users.

The number of JD.id website users accessing 1-10 times in a month is $64 \%$ or 256 users, accessing 11-20 times in a month is $24 \%$ or 96 users, and accessing 21-30 times in a month is $12 \%$ or 48 users.

Users of the JD.id website domiciled in Bandung dominate at 54\% or 216 users, in Semarang $19 \%$ or 76 users, in Jakarta $15 \%$ or 60 users, in Yogyakarta $7 \%$ or 28 users, in Surabaya 3\% or 12 users and in Tangerang $2 \%$ or as many as eight users. 


\subsection{Measurement Model Evaluation (Validity and Reliability)}

This research uses the SmartPLS software version 3.0 program to evaluate the measurement model and the structural model. The results of the evaluation of the measurement model consisting of validity and reliability tests can be seen in Table 2 and Table 3 below.

Table 2. Validity test

\begin{tabular}{|c|c|c|c|}
\hline Variable & Indicator & $\begin{array}{c}\text { Outer } \\
\text { loading }\end{array}$ & AVE \\
\hline \multirow{8}{*}{ Usability (X1) } & $\mathrm{X} 1 \mathrm{a}$ & 0.628 & \multirow{8}{*}{0.837} \\
\hline & $\mathrm{X} 1 \mathrm{~b}$ & 0.727 & \\
\hline & $\mathrm{X} 1 \mathrm{c}$ & 0.555 & \\
\hline & X1d & 0.533 & \\
\hline & $\mathrm{X} 1 \mathrm{e}$ & 0.536 & \\
\hline & X1f & 0.774 & \\
\hline & $\mathrm{X} 1 \mathrm{~g}$ & 0.683 & \\
\hline & $\mathrm{X} 1 \mathrm{~h}$ & 0.770 & \\
\hline \multirow{7}{*}{ Information quality (X2) } & $\mathrm{X} 2 \mathrm{a}$ & 0.706 & \multirow{7}{*}{0.737} \\
\hline & $\mathrm{X} 2 \mathrm{~b}$ & 0.504 & \\
\hline & $\mathrm{X} 2 \mathrm{c}$ & 0.564 & \\
\hline & $\mathrm{X} 2 \mathrm{~d}$ & 0.583 & \\
\hline & $\mathrm{X} 2 \mathrm{e}$ & 0.647 & \\
\hline & $\mathrm{X} 2 \mathrm{f}$ & 0.623 & \\
\hline & $\mathrm{X} 2 \mathrm{~g}$ & 0.612 & \\
\hline \multirow{5}{*}{ Service interaction (X3) } & $\mathrm{X} 3 \mathrm{a}$ & 0.560 & \multirow{5}{*}{0.799} \\
\hline & $\mathrm{X} 3 \mathrm{~b}$ & 0.740 & \\
\hline & $\mathrm{X} 3 \mathrm{c}$ & 0.858 & \\
\hline & $\mathrm{X} 3 \mathrm{~d}$ & 0.729 & \\
\hline & X3f & 0.733 & \\
\hline \multirow{4}{*}{$\begin{array}{l}\text { Customer's satisfaction } \\
\text { (Y1) }\end{array}$} & Y1a & 0.800 & \multirow{4}{*}{0.726} \\
\hline & Y1b & 0.766 & \\
\hline & Y1c & 0.673 & \\
\hline & Y1d & 0.727 & \\
\hline \multirow{4}{*}{ Customer’s loyalty (Y2) } & $\mathrm{Y} 2 \mathrm{a}$ & 0.764 & \multirow{4}{*}{0.776} \\
\hline & $\mathrm{Y} 2 \mathrm{~b}$ & 0.715 & \\
\hline & Y2c & 0.776 & \\
\hline & Y2d & 0.802 & \\
\hline
\end{tabular}

Table 2 shows that all indicators have an outer loading above 0.5, which means that all indicators are appropriate for measuring instruments to measure each variable. This shows that the relationship among variables is strong with the indicators. The validity of using AVE shows good results with AVE values above 0.5. This indicates that the indicators on a variable can be integrated and can represent these variables. The discriminant validity test using cross-loading shows that all indicators of the variable do not occur with a high correlation as shown by the cross-loading value of the indicator fulfilling the requirements of more than 0.5 . 
Table 3. Reliability test

\begin{tabular}{lll}
\hline \multirow{2}{*}{ Variable } & \multicolumn{2}{c}{ Reliability } \\
\cline { 2 - 3 } & $\begin{array}{l}\text { Construct } \\
\text { reliability }\end{array}$ & $\begin{array}{l}\text { Cronbach } \\
\text { 's Alpha }\end{array}$ \\
\hline Usability (X1) & 0.857 & 0.811 \\
\hline Information quality (X2) & 0.803 & 0.720 \\
\hline Service interaction (X3) & 0.840 & 0.768 \\
\hline Customer's satisfaction (Y1) & 0.831 & 0.727 \\
\hline Customer's loyalty (Y2) & 0.849 & 0.765 \\
\hline
\end{tabular}

Table 3 proves that the values of construct reliability and Cronbach's alpha used to test reliability show good reliability test results having values more than 0.7 . Table 2 and Table 3 show that the measuring instruments used in this research are valid and reliable.

Table 4. Discriminant Validity

\begin{tabular}{lccccc}
\hline & X2 & Y1 & Y2 & X3 & X1 \\
\hline Information Quality (X2) & & & & & \\
\hline Customer's satisfaction(Y1) & 0.821 & & & & \\
\hline Customer'sLoyality (Y2) & 0.665 & 0.824 & & & \\
\hline Service Interaction (X3) & 0.813 & 0.740 & 0.576 & & \\
\hline Usability (X1) & 0.790 & 0.690 & 0.526 & 0.817 & \\
\hline
\end{tabular}

From the HTMT results, the values in Table 4 indicated that there is no discriminant validity problems based on the HTMT 0.85 criteria. It implies that the HTMT criterion detects no collinearity problems among the latent constructs (multicollinearity). In other words, it contains zero overlapping items from the respondent perception in the affected constructs.

\subsection{Structural Model Evaluation (R-Square)}

After the model meets the criteria of the outer model (measurement model), the next step is to evaluate the inner model (structural model). The following is the value of the r-square for each construct examined [7], [18]. The value of r-square can be seen in the following Table 5.

Table 5. R-square value

\begin{tabular}{ll}
\hline & $R$-square \\
\hline Customer's satisfaction (Y1) & 0.565 \\
\hline Customer's loyalty (Y2) & 0.388 \\
\hline
\end{tabular}

From the r-square results in Table 5, it can be seen that the r-square value for the customer's satisfaction variable (Y1) is 0.565 , which means that the influence of usability variable (X1), information quality (X2) and service interaction (X3) is $56.5 \%$, while the remaining $43.5 \%$ is influenced by other factors outside of this model. Furthermore, the r-square result of customer's loyalty (Y2) is 0.388 , which means that 
the influence of customer's satisfaction variable (Y1) and usability variable (X1), information quality (X2), and service interaction (X3) directly is $38.8 \%$, while the remaining $61.2 \%$ is influenced by other factors outside of this model.

\subsection{Structural Model Evaluation (Q-Square)}

The Q-square evaluation was used to determine predictive relevance to endogenous factors (Y), which can be performed by blindfolding. The value of $\mathrm{Q}^{2}>0$ indicates that the model has predictive relevance. The value of $Q^{2}=0$ indicates that the model lacks predictive relevance [28]. The q-square results in this research can be seen in the following Table 6.

Table 6. Q-square value

\begin{tabular}{llll}
\hline Variable & Q-square & Predictive relevance & Conclusion \\
\hline $\begin{array}{l}\text { Customer's } \\
\text { satisfaction (Y1) }\end{array}$ & 0.293 & $\begin{array}{l}\text { There is predictive } \\
\text { relevance }\end{array}$ & Moderate \\
\hline $\begin{array}{l}\text { Customer's loyalty } \\
\text { (Y2) }\end{array}$ & 0.212 & $\begin{array}{l}\text { There is predictive } \\
\text { relevance }\end{array}$ & Moderate \\
\hline
\end{tabular}

Table 6 proves that the variables of customer's satisfaction (Y1) and customer's loyalty (Y2) have predictive relevance classified as moderate because the q-square values of the two variables are between 0.15 and 0.35 , which is 0.293 and 0.212 , respectively.

Table 6 proves that customer's satisfaction and customer's loyalty have a relatively moderate or moderate impact on the structural model in this research.

\subsection{Goodness-of-Fit Test}

The goodness of Fit $(\mathrm{GoF})$ is used to evaluate structural models and overall measurements and can be calculated using the following formula [28].

$$
\text { GoF }=\sqrt{\text { communality } \times R^{2}}
$$

Communality is obtained by averaging the results of the AVE from all variables, while the value of $R^{2}$ intended to calculate goodness-of-fit is the average of $R^{2}$. The average results of AVE and $R^{2}$ are shown in Table 7 .

Table 7. The average value of AVE and $R^{2}$

\begin{tabular}{lcc}
\hline Variable & AVE & $R^{2}$ \\
\hline Usability (X1) & 0.837 & - \\
\hline Information quality (X2) & 0.737 & - \\
\hline Service interaction (X3) & 0.799 & - \\
\hline Customer's satisfaction (Y1) & 0.726 & 0.565 \\
\hline Customer's loyalty (Y2) & 0.776 & 0.388 \\
\hline Average & 0.775 & 0.476 \\
\hline
\end{tabular}


Based on Table 7, the average of AVE and $\mathrm{R}^{2}$ is known, so that the goodness of fit in this research is equal to:

$$
\begin{gathered}
\text { GoF }=\sqrt{0.775 \times 0.476} \\
\text { GoF }=0.369
\end{gathered}
$$

The result of the goodness of fit on the whole model is 0.369 . This value proves that the overall model of either the structural model or the measurement model of this research can be considered strong because the value of the goodness of fit reaches more than 0.36. It indicates that the model of this research can predict influences well.

\subsection{Structural Model Evaluation (Importance Performance Map Analysis)}

Evaluation of structural model importance and IPMA is a two-dimensional map that is used to classify a construct or indicator based on the results of a survey that has been conducted to find suggestions for development based on scores of importance and performance from latent variables and indicators [27]. Determining the quadrant of IPMA can be conducted by averaging the results of the importance and performance of all variables.

\begin{tabular}{|c|c|c|}
\hline Variable & Performance & Importance \\
\hline Information quality (X2) & 68.69 & 0.593 \\
\hline Customer's satisfaction (Y1) & 71.363 & 0.739 \\
\hline Service interaction (X3) & 68.911 & 0.036 \\
\hline Usability (X1) & 65.686 & 0.038 \\
\hline Average & 68.8 & 0.315 \\
\hline
\end{tabular}

Table 8. The average value of variable importance and performance

Based on Table 8 , the average results of the performance at IPMA of this research amounted to 68.8 , while the importance of IPMA in this research was obtained at 0.315 .

Based on Figure 3, the importance of usability is 0.038 and the value of performance is 65.686. It shows that the usability variable belongs to quadrant 3, which means the variable does not need attention because of its low impact to affect JD.id consumer's loyalty. Service interaction has an importance value of 0.036 and the value of performance is 68.991, which is classified as quadrant 2. Data show that the service interaction variable needs to be allocated to other aspects of the website because too much attention is given to the JD.id website.

Information quality has an importance value of 0.593 and a performance value of 68.69. The result shows that the information quality variable belongs to quadrant 4 , which has the opportunity to be improved because it has high importance with low performance. Customer's satisfaction has an importance value of 0.739 and a performance value of 71.363. It shows that customer's satisfaction belongs to quadrant 1. 
Based on the data above, the JD.id website needs to focus on maintaining customer's satisfaction and also improving information quality because both variables show high importance to affect customer's loyalty.

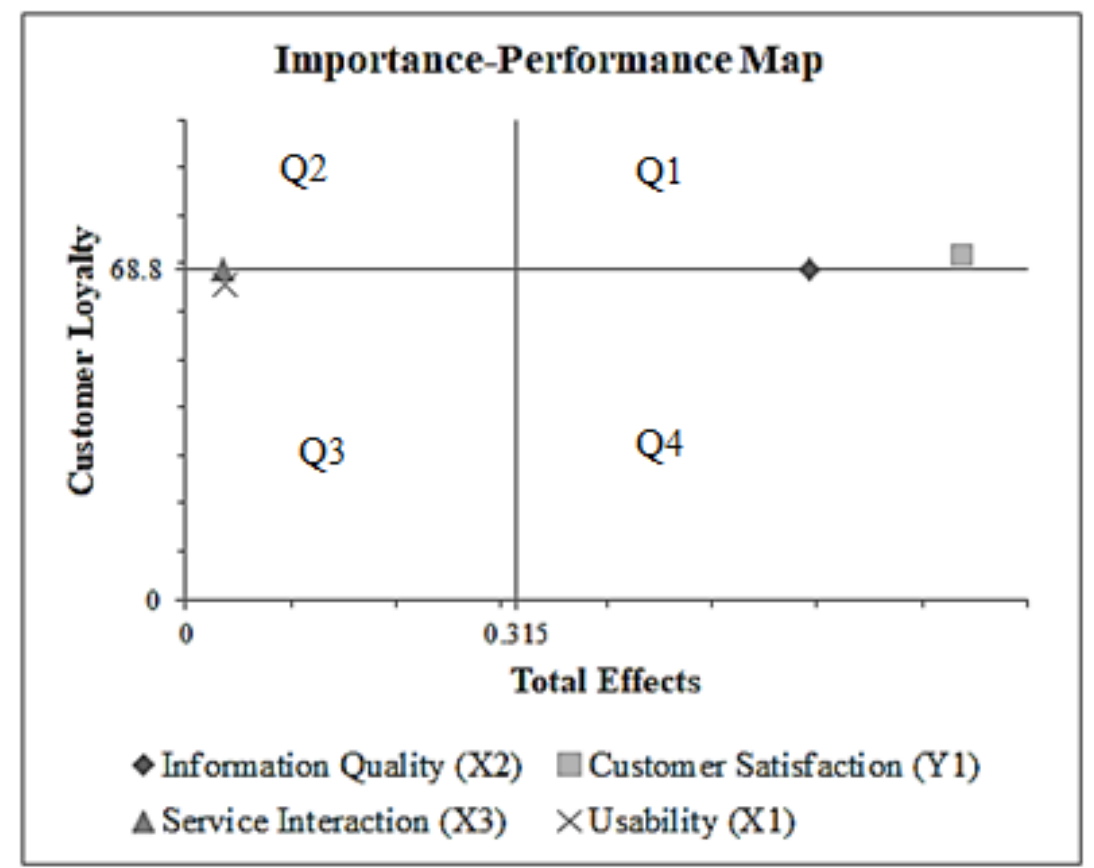

Figure 3. Result of IPMA variable

Based on Table 9, the results of the average performance from IPMA indicator are 68.00 and the results of the importance from IPMA indicator are known to be 0.009. IPMA results based on indicators can be seen in Figure 4.

Based on Figure 4, it can be seen that indicators included in quadrant 1 are $\mathrm{X} 2 \mathrm{a}$, $\mathrm{X} 2 \mathrm{~b}, \mathrm{X} 2 \mathrm{c}, \mathrm{X} 2 \mathrm{~g}, \mathrm{Y} 1 \mathrm{a}, \mathrm{Y} 1 \mathrm{~b}, \mathrm{Y} 1 \mathrm{c}$, and Y1d, which need to be maintained (high performance, high importance). Indicators included in quadrant 4 are X2d, X2e and $\mathrm{X} 2 \mathrm{f}$, which need improvement (low performance, high importance). Indicators included in quadrant 2 are X1b, X3c, X3d, X3f, and X3b, which need to be allocated more to other quadrants (high performance, low importance). Indicators included in quadrant 3 are X1a, X1c, X1d, X1e, X1f, X1g, X1h, and X3a, which don't need any attention (low performance, low importance).

Figure 4 also shows that all indicators of customer's satisfaction (Y1) need to be maintained. However, an indicator that needs more attention than the others is indicator number Y1a, which states the positive experience of customers to access and to do transactions in the JD.id.website. It has the highest importance of all indicators. Indicator number Y1b shows how customers assess the JD.id website suitable with their expectation, stated with the highest performance, while the indicators that need to be maintained at Information Quality (X2) are X2g and X2a, which state that information is presented accurately and information provided is detailed because they have the highest importance among other indicators. X2b states that reliable information provided by the JD.id website has the highest performance among information quality indicators. 
The indicators of information quality (X2) that need to be developed are X2d, $\mathrm{X} 2 \mathrm{e}$, and $\mathrm{X} 2 \mathrm{f}$ with the statement that the JD.id website provides product information related to the category searched, product information that is easy to understand and the information provided by JD.id website that is precise.

Table 9. The average value of indicator performance and importance

\begin{tabular}{lll}
\hline Indicator & Performance & Importance \\
\hline $\mathrm{X1a}$ & 65.83 & 0.004 \\
\hline $\mathrm{X} 1 \mathrm{~b}$ & 69.83 & 0.003 \\
\hline $\mathrm{X} 1 \mathrm{c}$ & 64.33 & 0.004 \\
\hline $\mathrm{X} 1 \mathrm{~d}$ & 67.00 & 0.004 \\
\hline $\mathrm{X} 1 \mathrm{e}$ & 67.83 & 0.004 \\
\hline $\mathrm{X} 1 \mathrm{f}$ & 59.92 & 0.004 \\
\hline $\mathrm{X} 1 \mathrm{~g}$ & 66.17 & 0.006 \\
\hline $\mathrm{X} 1 \mathrm{~h}$ & 65.50 & 0.008 \\
\hline $\mathrm{X} 2 \mathrm{a}$ & 71.25 & 0.143 \\
\hline $\mathrm{X} 2 \mathrm{~b}$ & 71.33 & 0.062 \\
\hline $\mathrm{X} 2 \mathrm{c}$ & 68.17 & 0.075 \\
\hline $\mathrm{X} 2 \mathrm{~d}$ & 65.50 & 0.076 \\
\hline $\mathrm{X} 2 \mathrm{e}$ & 66.42 & 0.069 \\
\hline $\mathrm{X} 2 \mathrm{f}$ & 63.25 & 0.059 \\
\hline $\mathrm{X} 2 \mathrm{~g}$ & 70.83 & 0.109 \\
\hline $\mathrm{X} 3 \mathrm{a}$ & 67.33 & 0.006 \\
\hline $\mathrm{X} 3 \mathrm{~b}$ & 66.83 & 0.009 \\
\hline $\mathrm{X} 3 \mathrm{c}$ & 68.58 & 0.008 \\
\hline $\mathrm{X} 3 \mathrm{~d}$ & 69.00 & 0.005 \\
\hline $\mathrm{X} 3 \mathrm{f}$ & 72.50 & 0.008 \\
\hline Y1a & 69.67 & 0.208 \\
\hline Y1b & 73.17 & 0.180 \\
\hline Y1c & 69.17 & 0.163 \\
\hline Y1d & 73.42 & 0.188 \\
\hline Average & 68.00 & 0.009 \\
\hline & &
\end{tabular}

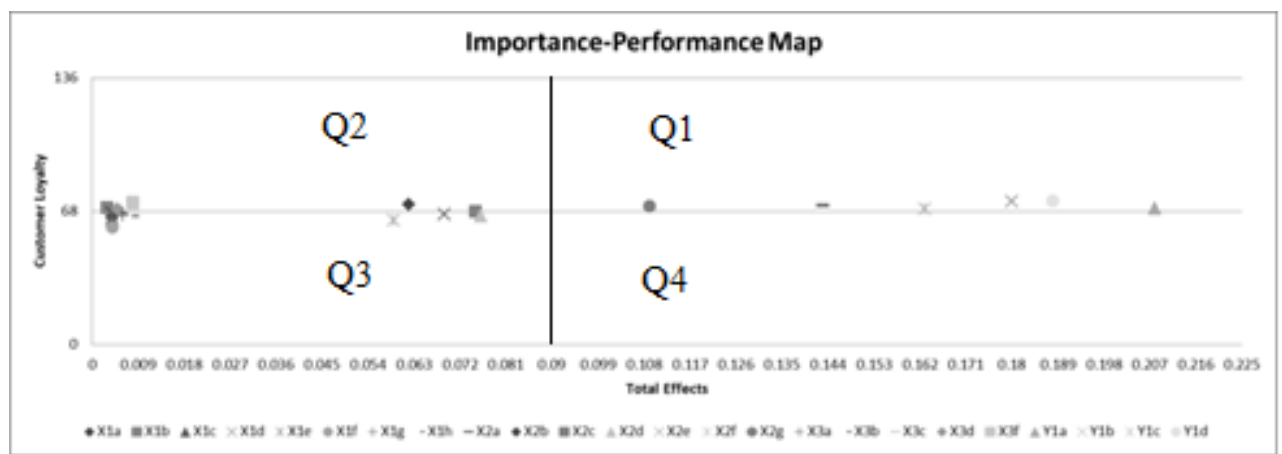

Figure 4. Result of IPMA indicator 


\subsection{Structural Model Evaluation (F-square)}

Evaluation of the f-square structural model is used to determine the effect size of the variables and to know how the predictors influence the latent variables in the structural model. If the value ranges from 0.05 , then it has a weak effect. If the value is more than 0.15 , then the variable has a strong effect. And, if the value exceeds 0.35 , then the variable has a strong effect [21]. The results of the f-square value can be seen in the following Table 10.

Table 10. F-square value

\begin{tabular}{lll}
\hline Variable & $\begin{array}{l}\text { Customer's } \\
\text { satisfaction (Y1) }\end{array}$ & $\begin{array}{l}\text { Customer's } \\
\text { loyalty(Y2) }\end{array}$ \\
\hline Usability (X1) & 0.002 & - \\
\hline Service interaction (X3) & 0.006 & - \\
\hline Information quality (X2) & 0.379 & - \\
\hline Customer's satisfaction (Y1) & - & 0.632 \\
\hline
\end{tabular}

The exogenous usability factor (X1) has a value of 0.002 , which has a weak effect on customer's satisfaction because the value is below 0.05 . Then, service interaction (X3) has a value of 0.006, which has a weak effect on customer's satisfaction because the value is less than 0.05 . Information quality (X2) has a value of 0.379, which has a strong influence on customer's satisfaction because the value is greater than 0.35 . Customer's satisfaction has a value of 0.632 , which has a strong influence on customer's loyalty because it has a value greater than 0.35 .

Table 10 shows that the variable that has the greatest effect or influence on customer's satisfaction is information quality (X2). It also shows that customer's satisfaction as a mediating factor has a great influence on customer's loyalty.

\subsection{Structural Model Evaluation (T-statistic)}

Evaluation of the t-statistical structural model was conducted to test the hypothesis t-value for each relationship among variables in this research. If the t-value is more than 1.96, the relationship among variables has a significant effect. If the tvalue is less than 1.96, the relationship among variables is not significant. The statistical results of the model are divided into two effects, direct effects and specific indirect effects. The results of the t-statistic effect (direct effect) are presented in Table 11.

Table 11. T-statistic value (direct effect)

\begin{tabular}{ccccc}
\hline Hypotheses & $\begin{array}{c}\text { Path } \\
\text { coefficient }\end{array}$ & T-statistic & P-value & Result \\
\hline $\mathrm{H} 1: \mathrm{X} 1 \rightarrow \mathrm{Y} 1$ & 0.043 & 0.969 & 0.333 & H1 Rejected \\
\hline $\mathrm{H} 2: \mathrm{X} 2 \rightarrow \mathrm{Y} 1$ & 0.658 & 11.228 & 0.000 & H2 Accepted \\
\hline $\mathrm{H} 3: \mathrm{X} 3 \rightarrow \mathrm{Y} 1$ & 0.079 & 1.300 & 0.194 & H3 Rejected \\
\hline $\mathrm{H} 4: \mathrm{Y} 1 \rightarrow \mathrm{Y} 2$ & 0.622 & 17.038 & 0.000 & H4 Accepted \\
\hline
\end{tabular}


T-statistic data show that the indicator of customer's satisfaction that contributes most to affect customer's loyalty is the indicator of a positive experience when customers access the JD.id website (Y1a). T-statistic data also show that the information quality indicator, which contributes most to affect customer's satisfaction, is the indicator of providing accurate information to JD.id website users (X2a).

However, it can be concluded that the variable of website quality that influences customer's satisfaction is information quality variable, while the other variables (usability and service interaction) do not positively influence customer's satisfaction. The data also show that customer's satisfaction has a positive influence on customer's loyalty.

Specific indirect effects in this research are presented in Table 12.

Table 12. T-statistic value (specific indirect effect)

\begin{tabular}{ccccc}
\hline Hypotheses & Path coef. & T-statistic & P-value & Result \\
\hline $\mathrm{H} 5: \mathrm{X} 1 \rightarrow \mathrm{Y} 1 \rightarrow \mathrm{Y} 2$ & 0.027 & 0.977 & 0.329 & H5 Rejected \\
\hline $\mathrm{H} 6: \mathrm{X} 2 \rightarrow \mathrm{Y} 1 \rightarrow \mathrm{Y} 2$ & 0.410 & 7.974 & 0.000 & H6 Accepted \\
\hline $\mathrm{H} 7: \mathrm{X} 3 \rightarrow \mathrm{Y} 1 \rightarrow \mathrm{Y} 2$ & 0.049 & 1.303 & 0.193 & H7 Rejected \\
\hline
\end{tabular}

Based on Table 12, hypothesis 6 is accepted because it has t-statistic value that exceeds the t-statistic value criterion. P-value fulfills the requirement of less than 0.05 with a high positive path coefficient. T-statistic data also show that the information quality indicator which contributes most to affect customer's satisfaction is the indicator of providing accurate information to JD.id website users (X2a).

Hypotheses 5 and 7 are rejected because they have a t-statistic value that does not meet the criterion for the t-statistic value of 1.96. P-value in both hypotheses does not meet the requirements of less than 0.05 and they have a small positive path coefficient.

Table 11 also shows that the variable of website quality that influences scustomer's loyalty is information quality (X2). Data also show that the other variables (usability and service interaction) do not positively influence customer's loyalty.

\subsection{Discussion}

The results based on SEM analysis of this research have similarities with previous research from Huy andTuyen[7] and previous research from Nugroho and Sari [29] who stated that information quality has a positive effect on customer's loyalty. It shows that providing various information about new features, new products and new events held on e-commerce websites can encourage website users to be interested in making transactions, which can increase profits from the JD.id website. In addition to encouraging users to make transactions, accurate shipping information can give a positive impression, which enhances the reputation of the JD.id website. Positive experience from website users over and over can lead users to be loyal, which can benefit the website, especially in revenue and website community development.

Based on IPMA data, indicators of information quality should be maintained to keep information given by website accurate and detailed by providing promotional 
videos to inform customers about the product. Besides, the website should provide detailed information about events, discount, promos, and flash sales, give notifications to users to remind them of events, and maintain information accuracy provided by the JD.id website, including the price that will be paid by the customer, product specifications and estimation of item arrival accurately to avoid any errors. Other than prioritizing accuracy and detail, reliable and updated information on the JD.id website, especially on JD news, needs more updated information, not only product introduction, but also information about new products or services provided in the future.

Other than maintaining information accuracy and details, some of the information quality needs improvement, such as providing product information related to the searched category by classifying products not only from the category, but also based on the brand and price range so that customers find it easy to look for the product based on their preference. Other than related information, the JD.id website can also improve by providing product information that is easy to understand, and precise information of the products by adding the best product information in the category the customer is looking for, as well as providing a description or specification of a product that is easily understood by customers.

Moreover, customer's satisfaction as a mediating factor based on SEM analysis in this research is supported by Huy and Tuyen[7], Nugroho and Sari [29], and Kartikasari[8] who state that customer's satisfaction has a positive effect on customer's loyalty. It indicates that customers who access the JD.id website are satisfied in the process of accessing or doing transactions.

Based on data Importance Performance Map Analysis (IPMA), all indicators of customer's satisfaction should be maintained. However, the highest priority indicator to be maintained is the positive experience of customers in accessing websites and doing transactions by organising the menu on the website better so that users can be easy and comfortable in finding the desired item, as well as increasing loading page speed on the JD.id website.

Usability and service interaction are not positively related to customer's satisfaction and customer's loyalty. This result does not support the proposal discussed by Le Van Huy[7] and Kartikasari[8]. It shows that, based on SEM analysis, usability aspects, such as design, display, and navigation on the JD.id website, are not positively related to customer's satisfaction that can lead to loyalty. Data also show that service interaction provided on the JD.id website is not positively related to customer's satisfaction that can lead to loyalty.

IPMA data show that the usability aspect of the JD.id website does not need additional attention because website design and navigation have a low impact to affect positive experience in accessing the JD.id website. Data also show that the service of the JD.id website needs to be allocated more to information quality because it has greater attention.

Variables we recommend to improve customer's loyalty on the e-commerce retailers are as follows: maintaining the quality of information by providing accurate and trustworthy information about the product, the event, discount promos, as well as flash sale that will be carried out on the website, providing further information to the users by giving link of promo video, providing notifications to the user to remind the event to be held by the website, maintaining the accuracy of information from the 
website, starting from the price to be paid by the customer, product specifications, estimation of item arrival accurately to avoid any errors, improving the quality of information that is more relevant when customers search the desired product by adding best information to the products in the category the customer is looking for, as well as providing detailed information or specification of a product that is easily understood by users or customers, maintaining customers to stay long in accessing the JD.id website by organizing well the menu on the website so that users are easy and convenient in finding the desired item, as well increasing speed in loading pages of the JD.id website.

For further customer's loyalty research we recommend adding other variables such as product pricing and promotion that can affect customer's satisfaction which leads to customer's loyalty on the e-commerce website and we recommend adding more mediating variables such as trust.

\subsection{Research Limitation and Future Research Direction.}

The limitation of this research is that most respondents are from young people that have ages from range 17- 24 years old (66\%). So if the range of age is more distributed to others, it can be representative of some generations. Furthermore, another factor that has a relation with loyalty is not only satisfaction, but can also be trust[30]. This research focuses only on satisfaction.

For future research, adding another factor that has a relation with loyalty is important in order to have precise results such as trust.

\section{CONCLUSION}

Based on the research, we conclude that the website quality variable that has the most significant influence on customer's satisfaction and customer's loyalty of the JD.id website is the variable of information quality. The other variables, such as usability and service interaction, have no positive effect and are not significant to customer's satisfaction with little influence. Customer's satisfaction, which acts as a mediating variable, has a positive and significant effect on customer's loyalty with very strong influence. It should be maintained to retain the loyalty of the customer.

Based on importance-performance map analysis of customer's loyalty, some variables that must be improved to develop customer's loyalty on the JD.id website are the variables of maintaining accurate and detailed information by adding promotional videos about products, developing related content to make it easy to understand, and providing precise information by adding more classifications to the product searched. On the other hand, items that have a low impact on customer's loyalty are design, display, and navigation of the JD.id website and service interaction.

\section{REFERENCES}

[1] Statista, "Number of internet users in Indonesia 2022 Statista," Statista, 2017. [Online]. Available: https://www.statista.com/statistics/254456/number-ofinternet-users-in-indonesia/. [Accessed: 13-Dec-2018].

[2] Statista, "Indonesia: retail e-commerce sales 2016-2022 | Statistic," Statista, 2017. [Online]. Available: https://www.statista.com/statistics/280925/b2c-ecommerce-sales-in-indonesia/. [Accessed: 13-Dec-2018]. 
[3] Arhando Pramdia Julianto, "JD.ID Siap Bertarung di Pasar E-commerce Indonesia - Kompas.com," Kompas, 2017. [Online]. Available: https://ekonomi.kompas.com/read/2017/08/31/143720926/jdid-siap-bertarung-dipasar-e-commerce-indonesia. [Accessed: 13-Dec-2018].

[4] A. Hadi Pratama, "Strategi JD.ID untuk Bersaing di Bisnis E-commerce Tanah Air," techinasia, 2017. [Online]. Available: https://id.techinasia.com/strategi-jdid-indonesia. [Accessed: 19-Dec-2018].

[5] A. Pathania and G. Rasool, "Investigating e tailer's perceived Website Quality using Analytical Hierarchy Process Technique," Procedia Comput. Sci., vol. 122, pp. 1016-1023, 2017.

[6] V. Gaffar, Manajemen Bisnis. Bandung: Alfabeta, 2007.

[7] L. Van Huy and P. D. Tuyen, "The Relationship among Website Quality, Consumer Satisfaction, and Loyalty in Vietnamese Banking Sector," J. Econ. Dev., vol. 22, no. 3, pp. 81-101, 2015.

[8] P. Kartikasari, "Pengaruh Kualitas Sistem Informasi Cyber Campus Terhadap Kepuasan dan Loyalitas Mahasiswa STIKOM Surabaya," Jatisi, vol. 3, no. 2, pp. 169-182, 2017.

[9] H. Siagian and E. Cahyono, "Analisis Website Quality, Trust Dan Loyalty Pelanggan," J. Manaj. Pemasar., vol. 8, no. 2, pp. 55-61, 2014.

[10] S. Barnes and R. Vidgen, "WebQual: An Exploration of Web-Site Quality. WebQual : An Exploration of Web-site Quality," no. January, 2000.

[11] R. Kurniawan, A. Kusumawati, and S. Priambada, "Kepercayaan Dan Dampaknya Pada Keputusan Pembelian Pada Website E-Commerce ( Studi pada Konsumen PT . B )," J. Adm. Bisnis, vol. 62, no. 1, pp. 198-206, 2018.

[12] P. Kotler and K. L. Keller, "Marketing Management," 15e ed., B. Sabran, Ed. Edinburgh Gate: Pearson Education Limited, 2016.

[13] M. Konečnik Ruzzier, M. Ruzzier, and R. Hisrich, "Value, satisfaction and customer's loyalty," Mark. Entrep. SMEs, no. November, pp. 21-36, 2014.

[14] J. Fulcher, "Customer's satisfaction," Manuf. Syst., vol. 15, no. 1, p. 66, 1997.

[15] Griffin Jill, Customer's loyalty:Menumbuhkan dan Mempertahankan Kesetiaan Pelanggan, 2nd ed. Erlangga, 2005.

[16] Indrawati, Metode Penelitian Manajemen dan Bisnis, 1st ed. Bandung: PT Refika Aditama, 2015.

[17] E. A.- Manasra, "Mohammed Khair" Saleem Abu Zaid, and F. TaherQutaishat, "Investigating the Impact of Website Quality on Consumers' Satisfaction in Jordanian Telecommunication Sector," Arab Econ. Bus. J., vol. 8, no. 1-2, pp. 31-37, 2013.

[18] Z. bt Khalifah, W. C. Bing, and N. H. Hashim, "The Influence of Website Quality Dimensions on Customer's satisfaction in Travel Website," Ijsch.Com, vol. 8, no. 11, pp. 3438-3444, 2015.

[19] D. Napitupulu, "Analysis of Factors Affecting The Website Quality (Study Case: XYZ University)," Int. J. Adv. Sci. Eng. Inf. Technol., vol. 7, no. 3, p. 792, 2017.

[20] A. M. Al-Agaga, "Factors That Influence E-Loyalty of Internet Banking Users," Int. J. Electron. Commer. Stud., vol. 3, no. 2, pp. 297-304, 2012.

[21] L. S. Liong, H. H. Tat, A. Rasli, and A. Jusoh, "Relationship Between Service Quality, Satisfaction, and Loyalty of Google," Int. J. Electron. Commer. Stud., vol. 2, no. 1, pp. 35-56, 2011.

[22] S. Das, A. Mishra, and D. Cyr, "Opportunity gone in a flash: Measurement of ecommerce service failure and justice with recovery as a source of e-loyalty," Decis. Support Syst., vol. 125, no. December 2018, p. 113130, 2019. 
[23] J. F. Hair, W. C. Black, B. J. Babin, and R. E. Anderson, Multivariate Data Analysis, 7th ed. Edinburgh Gate: Pearson Education Limited, 2014.

[24] M. R. Ab Hamid, W. Sami, and M. H. Mohmad Sidek, "Discriminant Validity Assessment: Use of Fornell \& Larcker criterion versus HTMT Criterion," J. Phys. Conf. Ser., vol. 890, no. 1, 2017.

[25] J. F. Hair, C. M. Ringle, and M. Sarstedt, "Editorial Partial Least Squares Structural Equation Modeling: Rigorous Applications, Better Results and Higher Acceptance," Long Range Plann., vol. 46, pp. 1-12, 2013.

[26] K. K. Wong, "Partial Least Squares Structural Equation Modeling ( PLS-SEM ) Techniques Using SmartPLS," Mark. Bull., vol. 24, 2013.

[27]C. M. Ringle and M. Sarstedt, "Gain More Insight from Your PLS-SEM Results : The Importance-Performance Gain more insight from your PLS-SEM results The importance-performance map analysis," no. February, 2016.

[28] I. Ghozali and H. Latan, Partial Least Square Konsep, Teknik dan Aplikasi Menggunakan Aplikasi SmartPLS 3.0, 2nd ed. Semarang: Undip, 2015.

[29] A. K. Nugroho and P. K. Sari, "Analisis Pengaruh Kualitas Website Tokopedia Terhadap Kepuasan Pengguna Menggunakan Metode Webqual 4 . 0 The Effect Analysis Of Tokopedia Website Quality Towards User Satisfaction Using Webqual 4 . 0 Method," e-Proceeding Manag., vol. 3, no. 3, pp. 2930-2937, 2016.

[30] S. M. C. Loureiro, "The effect of perceived benefits, trust, quality, brand awareness/associations and brand loyalty on internet banking brand equity," Int. J. Electron. Commer. Stud., vol. 4, no. 2, pp. 139-158, 2013. 